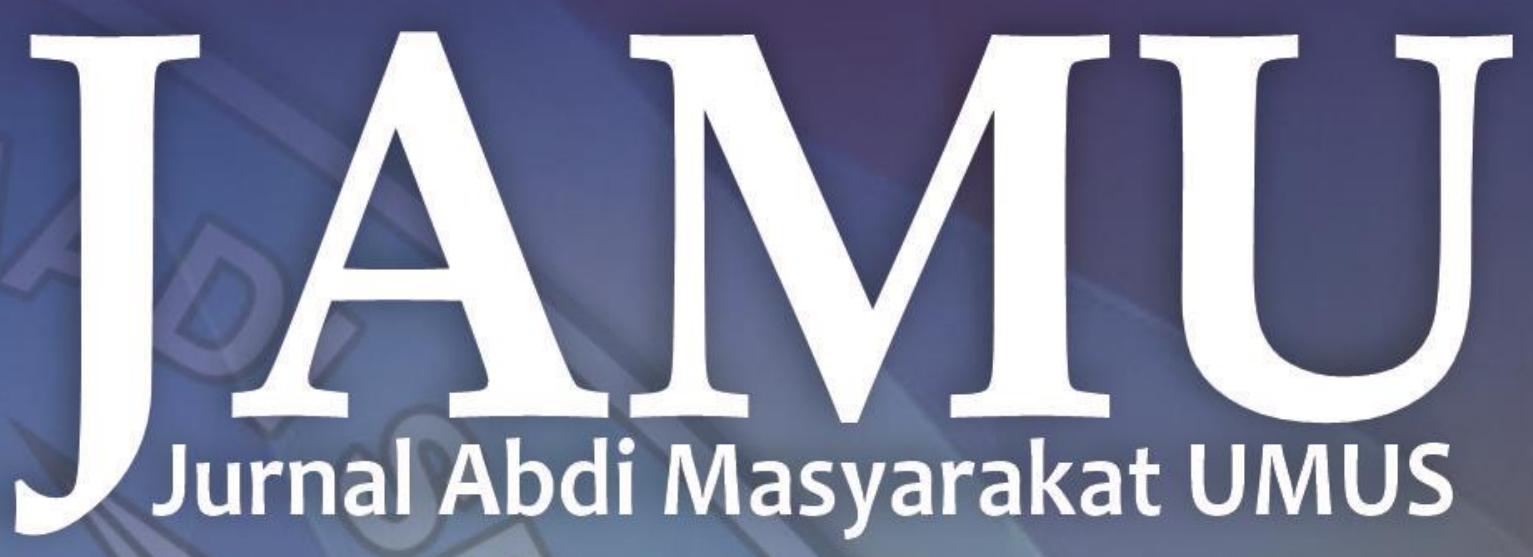




\section{EDITOR IN CHIEF}

Ubaedillah, M.Pd

\section{MANAGING EDITOR}

Harliana, ST., M.Cs

\section{PRINCIPAL CONTACT}

Rifatul Masrikhiyah, S.Tp., M.Si

\section{SUPPORT CONTACT}

Laelia Nurpratiwiningsih, M.Pd

\section{MITRA BESTARI (STAFF AHLI)}

Dr. Roby Setiadi, S.Kom., M.M (Universitas Muhadi Setiabudi, Brebes)

Otong Saeful Bachri, S.Kom., M.Kom (Universitas Muhadi Setiabudi, Brebes)

Dr. Moh. Toharudin, M.Pd (Universitas Muhadi Setiabudi, Brebes) Atikah Mumpuni, M.Pd (Universitas Muhadi Setiabudi, Brebes)

Dr. Heru Ismanto, S.Si., M.Cs (Universitas Musamus Merauke, Papua) Dr. Wuri Wuryandani, M.Pd (Universitas Negeri Yogyakarta)

Dr. Nanik Sulistyani, M.Si., Apt (Universitas Ahmad Dahlan, Yogyakarta)

Dina Rahayuning Pangestuti, S.TP., M.Gizi (Universitas Diponogoro) Jasanta Peranginangin, S.E., M.M (Sekolah Tinggi Pariwisata Sahid Surakarta)

Dr. Lili Karmela Fitriani, S.E., M.Si (Universitas Kuningan, Jawa Barat)

\section{PENANGGUNGJAWAB :}

Rektor Universitas Muhadi Setiabudi Brebes

\section{ALAMAT PENYUNTING:}

LP3M Universitas Muhadi Setiabudi Brebes.

Jalan Pangeran Diponogoro KM 2 Wanasari Brebes - Jawa Tengah 52252. Telp (0283) 6199000 


\section{JAMU}

Jurnal Abdi Masyarakat UMUS

\section{KATA PENGANTAR}

Assalamualaikum Wr, Wb

Puji syukur kehadirat Allah SWT atas anugrahnya sehingga jurnal edisi kali ini dapat terbit. Sebelumnya kami ingin mengucapkan terimakasih banyak kepada dosen/peneliti/profesi yang telah mengirimkan artikelnya kepada dewan redaksi untuk dapat dipublish pada jurnal yang kami kelola. Semua artikel yang masuk kepada dewan redaksi telah melalui proses review oleh mitra bestari dan tim dewan redaksi, segala proses revisi dan redaksional juga telah dilakukan oleh penulis sebelum jurnal ini diterbitkan. Segala bentuk kritik dan saran yang membangun dari pembaca / peneliti yang dikirimkan sangat kami harapkan demi melakukan pembenahan jurnal yang kami kelola. Akhir kata kami menghaturkan terimakasih banyak kepada semua pihak yang sudah terlibat dalam proses penerbitan jurnal ini.

Wassalamualaikum wr wb.

Ketua Dewan Redaksi 


\section{DAFTAR ISI}

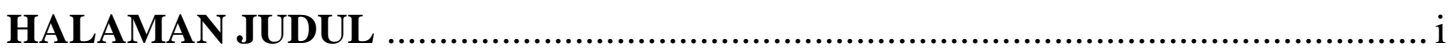

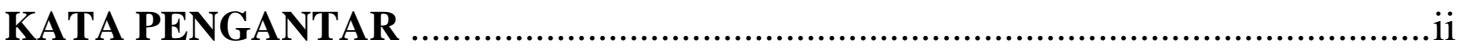

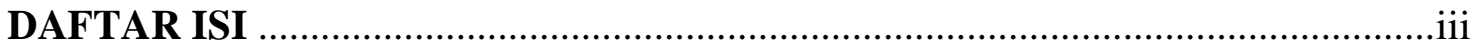

Pemberdayaan Anak Usia Sekolah Dalam Menumbuhkan Nilai Karakter Melalui Strategi Pembiasaan Di PPSA Tegal

Moh. Toharudin ${ }^{1}$, Laelia Nurpratiwiningsih ${ }^{2}$, Gian Fitralisma ${ }^{3}$

${ }^{(1,2)}$ Program Studi Pendidikan Guru Sekolah Dasar, Fakultas Keguruan dan Ilmu Pendidikan Universitas Muhadi Setiabudi

${ }^{3}$ Program Studi Manajemen, Fakultas Ekonomi dan Bisnis, Universitas Muhadi Setiabudi) $\quad$ 1-7

Menstimulasi Kemampuan Berbicara Pada Anak Usia Dini Berbasis Media Dongeng Agnes Apryliana ${ }^{1}$, Kiki Purwati ${ }^{2}$

${ }^{(1,2)}$ Program Studi Pendidikan Bahasa dan Sastra Indonesia, Fakultas Keguruan dan Ilmu Pendidikan, Universitas Muhadi Setiabudi)

Pemanfaatan E-Commerce Terhadap Penjualan Kendang Jimbe Blitar Harliana $^{1)}$, Roby Setiadii ${ }^{2}$, Otong Saeful Bachri ${ }^{3)}$, Khalid Iskandar ${ }^{4)}$, Gagas Prasetya ${ }^{5)}$ ${ }^{(1,3,5)}$ Program Studi Teknik Informatika, Fakultas Teknik, Universitas Muhadi Setiabudi ${ }^{2,4)}$ Program Studi Manajemen, Fakultas Ekonomi dan Bisnis, Universitas Muhadi Setiabudi) 15-20

Manajemen Tatakelola BUMDES: Mengelola Pemasaran Produk

Andi Yulianto ${ }^{1)}$, Mukson ${ }^{2)}$, Otong Saeful Bachri ${ }^{3)}$, Slamet Bambang Riono ${ }^{4)}$, Yenny Ernitawati ${ }^{5)}$ ${ }^{(1,2,4)}$ Program Studi Manajemen, Fakultas Ekonomi dan Bisnis, Universitas Muhadi Setiabudi ${ }^{5)}$ Program Studi Akuntansi, Fakultas Ekonomi dan Bisnis, Universitas Muhadi Setiabudi)

${ }^{3)}$ Program Studi Teknik Informatika, Fakultas Teknik, Universitas Muhadi Setiabudi)

Penggunaan Kartu Huruf dan Peramainan Mencari Kartu Huruf Untuk Peningkatan Pengenalan Huruf

Muhammad Toha $^{1)}$, Armyta Puspitasari ${ }^{2}$, Ubaedillah ${ }^{3)}$, Farhan Saefudin Wahid ${ }^{4)}$, Laelia Nurpratiwiningsih ${ }^{5}$

${ }^{(1,3)}$ Program Studi Pendidikan Bahasa dan Sastra Indoensia, Fakultas Keguruan dan Ilmu Pendidikan, Universitas Muhadi Setiabudi,

2)Teknologi Bangunan dan Jalur Perkretaapian, Politeknik Perkretaapian Indonesia,

${ }^{4,5}$ Program Studi Pendidikan Guru Sekolah Dasar, Fakultas Keguruan dan Ilmu Pendidikan, Universitas Muhadi Setiabudi)

${ }^{3)}$ Program Studi Manajemen, Fakultas Ekonomi dan Bisnis, Universitas Muhadi Setiabudi)

$28-33$ 


\section{Menumbuhkan Sikap Sadar Lingkungan Bagi Anak Usia Sekolah Dasar}

Laelia Nurpratiwiningsih ${ }^{1)}$, Teguh Arifianto ${ }^{2)}$, Wildan Qosid ${ }^{3)}$, Ubaedillah ${ }^{4)}$

(1,3)Program Studi Pendidikan Guru Sekolah Dasar, Fakultas Keguruan dan Ilmu Pendidikan, Universitas Muhadi Setiabudi,

${ }^{2)}$ Teknologi Elektro Perkretaapian, Politeknik Perkretaapian Indonesia,

$\left({ }^{4}\right.$ Program Studi Pendidikan Bahasa dan Sastra Indonesia, Fakultas Keguruan dan Ilmu Pendidikan,

Universitas Muhadi Setiabudi)

Peningkatan Pengetahuan Mengenai Manfaat Pangan Probiotik dan Prebiotik Bagi Kesehatan

Rifatul Masrikhiyah ${ }^{1)}$, Henry Widya Prasetya ${ }^{2)}$, Ubaedillah $^{3)}$, Rifqi Ferry Balfas ${ }^{4}$, Susi Yulianingsih ${ }^{5)}$ ${ }^{1,5}$ Program Studi Ilmu Gizi, Fakultas Kesehatan, Universitas Muhadi Setiabudi,

${ }^{2)}$ Teknologi Mekanika Perkretaapian, Politeknik Perkretaapian Indonesia,

${ }^{3}$ Program Studi Pendidikan Bahasa dan Sastra Indonesia, Fakultas Keguruan dan Ilmu Pendidikan, Universitas Muhadi Setiabudi,

4)Program Studi Ilmu Gizi, Fakultas Ilmu Kesehatan, Universitas Muhadi Setiabudi) $\quad$ 42-46

\section{Pelatihan Wawancara Kerja Dalam Bahasa Inggris Bagi Siswa SMK Menggunakan}

Metode Demonstrasi

Ubaedillah $^{1)}$, Damar Isti Pratiwi ${ }^{2)}$, Mukson $^{3)}$, Rifatul Masrikhiyah ${ }^{4)}$, Laelia Nurpratiwiningsih ${ }^{5)}$

( ${ }^{1}$ Program Studi Pendidikan Bahasa dan Sastra Indonesia, Fakultas Keguruan dan Ilmu Pendidikan, Universitas Muhadi Setiabudi,

2) Teknologi Mekanika Perkretaapian, Politeknik Perkretaapian Indonesia.

${ }^{3}$ Program Studi Manajemen, Fakultas Ekonomi dan Bisnis, Universitas Muhadi Setiabudi,

${ }^{4)}$ Program Studi Ilmu Gizi, Fakultas Ilmu Kesehatan, Universitas Muhadi Setiabudi

${ }^{5)}$ Program Studi Guru Sekolah Dasar, Fakultas Keguruan dan Ilmu Pendidikan, Universitas Muhadi Setiabudi) 


\title{
MENUMBUHKAN SIKAP SADAR LINGKUNGAN BAGI ANAK USIA SEKOLAH DASAR
}

\author{
Laelia Nurpratiwiningsih"1, Teguh Arifianto ${ }^{2}$, Wildan Qosid ${ }^{3}$, Ubaedillah ${ }^{4}$ \\ ${ }^{1,3}$ Program Studi Pendidikan Guru Sekolah Dasar, Fakultas Keguruan dan Ilmu Pendidikan, \\ Universitas Muhadi Setiabudi Brebes \\ ${ }^{2}$ Teknologi Elektro Perkretaapian, Politeknik Perkretaapian Indonesia \\ ${ }^{4}$ Program Studi Pendidikan Bahasa dan Sastra Indonesia, Fakultas Keguruan dan Ilmu \\ Pendidikan, Universitas Muhadi Setiabudi Brebes \\ e-mail: ${ }^{1}$ laelia.np89@gmail.com, ${ }^{2}$ teguh@ppi.ac.id, ${ }^{3}$ ajawildan889@gmail.com, \\ ubaedillah@umus.ac.id
}

\begin{abstract}
The environment is very important to society, because it is interconnected between living creatures and surrounding areas. The implementation of a clean and healthy environment needs to be implemented early. In its application environmental awareness can be applied in elementary school. Elementary school age children need to be aware of wasting garbage in their place. The types of garbage that exist in the community environment are very variant, so it is necessary to be known and chosen by the child in throwing. The method of implementation of make a match method using image media and question and answer. Results showed that elementary school-age children were enthusiastic in cultivating environmental awareness and simply having an understanding of the environmental conscious attitude. In addition, the child has an understanding related to the types of garbage in the surrounding environment.
\end{abstract}

Keyword - conscious attitude, environment.

\section{PENDAHULUAN}

Lingkungan merupakan semua hal yang ada di sekeliling manusia dan mencakup keadaan sumber daya alam serta dapat mempengaruhi kehidupannya baik secara langsung maupun tidak langsung. Jadi, Lingkungan ini merupakan hal yang sangat penting bagi kehidupan masyarakat. Tanpa adanya lingkungan, masyarakat tidak dapat beraktivitas sehari-hari. Pentingnya lingkungan bagi kehidupan sebenarnya sudah disadari bagi sebagian masyarakat sekitar. Namun, penerapannya belum dilaksanakan secara maksimal. Masih ada yang meremehkan akan pentingnya lingkungan dan masih ada yang memanfaatkan lingkungan hanya untuk kepetingan pribadi.

Menurut Undang-Undang Republik Indonesia Nomor 32 Tahun 2009, Lingkungan adalah kesatuan ruang dengan semua benda, daya, keadaan dan makhluk hidup termasuk manusia dan perilakunya, yang mempengaruhi kelangsungan kehidupan dan kesejahteraan manusia serta makhluk hidup lain.

Lingkungan dapat dikelompokkan menjadi komponen abiotik dan biotik. Komponen abiotik merupakan segala yang tidak bernyawa, seperti: air, udara iklim. Sedangkan komponen biotik merupakan segala sesuatu yang bernyawa, seperti: hewan, tumbuhan dan manusia. Berkaitan dengan hal tersebut, maka komponen terkait dengan lingkungan perlu dipahami oleh peserta didik.

Penerapan lingkungan hidup yang sehat dan bersih perlu dilakukan secara maksimal dan dapat diterapkan sejak dini. Hal tersebut juga dapat dilakukan di lingkungan sekolah. Anak sekolah dapat menerapkan dalam kegiatan belajar belajar maupun kegiatan di lingkungan sekolah. Salah satu cara hal yang sangat sederhana dengan menjaga lingkungan adalah tidak merusak 
lingkungan dan membuang sampah pada tempatnya. Tempat sampah yang tersedia di sekolah masih minimalis, belum sesuai dengan standar yang ada. Tempat sampah yang tersedia pun masih belum digunakan secara maksimal. Masih terdapat siswa yang membuang sampah bukan pada tempatnya. Dan salah satu dampak dari membuang sampah sembarangan adalah tersumbatnya aliran air di lingkungan sekolah. Hal ini dapat menyebabkan banjir, jika terjadinya intensitas hujan yang sangat deras. Sehingga mengakibatkan aliran air tidak dapat mengalir dengan lancar.

Selain itu, sampah ini dapat menimbulkan hal negatif bagi anak. Menurut Juariah (2018), Kebersihan diri yang buruk dapat meningkatkan terinfeksinya berbagai penyakit bagi anak usia sekolah. Anak aktif bermain di luar ruangan terutama pada benda yang dapat menimbulkan penyakit. Maka dari itu perlu adanya pengetahuan akan pentingnya kesehatan.

Sampah merupakan barang yang sudah terpakai lagi. Bahkan dalam penerapan kehidupan sehari-hari, masih banyak masyarakat yang belum memahami jenisjenis sampah dan bagaimana cara membuang sampah yang benar dan tepat. Sumber sampah bisa berasal dari alam, manusia, konsumsi, industri kimia dan industri logam. Namun, jika dilihat dari sifatnya, sampah dapat dikelompokkan menjadi sampah organik dan sampah nonorganik.

Berkaitan dengan hal tersebut, banyaknya jenis sampah tersebut, maka perlu adanya perlakuan yang benar dari masyarakat sekitar. Sehingga hal ini tidak memberikan dampak negatif bagi masyarakat sekitar. Jika masyarakat dapat mengolah dengan baik sampah yang ada, maka bisa memberikan dampak yang baik pula bagi lingkungan sekitarnya.

Afriyeni (2018) menyatakan bahwa pembentukan karakter anak untuk peduli lingkungan yang ada di Sekolah Adiwiyata Mandiri memberikan dampak bagi sekolah. Sekolah lebih berperan aktif dalam menciptakan kawasan yang peduli dengan lingkungan dan dapat menciptakan siswasiswi sadar akan lingkungan. Selain itu, kegiatan tersebut dapat mengurangi global warming.

Sikap merupakan perasaan dan pikiran seseorang dalam bertingkah laku saat sedang menyukai sesuatu atau tidak menyukai sesuatu. Komponen dalam sikap dapat meliputi emosi, perilaku dan kognisi. Sehingga seorang ketika menghadapi masalah tergantung dari cara menghadapi masalah.

Sikap anak didik peduli lingkungan dapat melakukan cara-cara, antara lain; membuang sampah pada tempatnya, berhemat menggunakan listrik dan air, mengenal R3 (reduce, reuse dan recycle), menggunakan produk yang ramah lingkungan, meminimalisasi penggunaan kendaraan pribadi, belajar menanam pohon dan berkebun dan bepergian ke alam bebas. Salah satu cara yang sederhana dan dapat dilakukan anak usia sekolah dasar dengan cara membuang sampah pada tempatnya dan mengenal R3 (reduce, reuse dan recycle).

Salah satu sekolah di Brebes yang pernah terjadi banjir di sekitar sekolah adalah SD Negeri Pesantunan 01. SD ini merupakan salah satu SD di jl. Maijen Sungkono, desa Pesantunan, Kecamatan Wanasari, Kabupaten Brebes, Provinsi Jawa Tengah, kode pos 52221. NPSN sekolah tersebut 20326184. Tanggal SK operasional 1 Januari 1910, dengan memiliki akreditasi B dan no. SK Akreditasi 12/BAN-SM. Sekolah ini memiliki luas tanah $2 \mathrm{~m}^{2}$ dan dilengkapi dengan akses internet telkomsel flash serta sumber listrik dari PLN. Fasilitas di sekolah sudah cukup lengkap, namun perlu adanya kesadaran akan pentingnya lingkungan. Kesadaran akan pentingnya lingkungan dapat dilakukan di lingkungan sekolah. Sasaran yang ditujukan adalah anak usia sekolah dasar.

Anak usia sekolah dasar ini merupakan anak yang masih labil dan dinamis dalam bersikap. Dalam menerapkan kesadaran lingkungan hidup, perlu dilakukan secara perlahan. Anak masih belum memahami terkait dengan jenis-jenis sampah di sekitarnya, sehingga dalam membuang sampah belum dapat menempatkan pada tempatnya. Selain itu, anak masih sembarangan dalam membuang sampah. 
Karakteristik anak sekolah dasar, antara lain; memiliki rasa ingin tahu yang kuat dan tertarik pada lingkungan sekitar, sengang bermain, suka mengeksplorasi usaha baru, belajar dengna cara mengobservasi dan berinisiatif. Karakter ini merupakan jati diri bagi individu. Sehingga perlu dilakukan sedini mungkin agar tercipta kualitas Sumber Daya Manusia yang baik.

Oleh karena itu, perlu adanya suatu cara untuk menumbuhkan sikap sadar lingkungan bagi anak usia sekolah dasar di SD N Pesantunan 01. Cara yang dapat dilakukan dengan melalui sosialisasi dan pelatihan bagi anak usia sekolah dasar. Hal ini diharapkan agar peserta didik dapat menjaga dan melestarikan di lingkungan sekitarnya, sehingga kegiatan belajar menjaga semakin semangat.

Hal ini sesuai dengan hasil jurnal Widyaningrum, bahwa sosialisasi program sekolah peduli dan berbudaya lingkungan dapat meningkatkan sikap peduli lingkungan dan ilmiah siswa sekolah dasar, selain itu dapat meningkatkan pemahaman dan ketrampilan guru dalam merancang perangkat pembelajaran.

\section{METODE PELAKSANAAN}

Sasaran dalam pengabdian kepada masyarakat ini adalah anak usia sekolah dasar, dimana anak berada di lingkungan sekolah. Anak usia sekolah dasar ini merupakan anak yang sedang melakukan kegiatan belajar mengajar di SD $\mathrm{N}$ Pesantunan 01. Usia anak sekolah dasar tersebut adalah 7-12 tahun. Jadi, dari peserta didik kelas I-VI.

Tahapan pelaksanaan pengabdian masyarakat dimulai dari persiapan dalam menentukan sosialisasi kepada anak usia sekolah dasar. Segala persuratan dan perijinan dipersiapkan sebelum melakukan sosialisasi. Perijinan ini dari pihak Lembaga Pembelajaran, Penelitian dan Pengabdian kepada Masyarakat (LP3M) UMUS dan dari pihak sekolah. Kemudian dilanjutkan dengan pelaksanaan kegiatan sosialisasi yang dilakukan di SD $\mathrm{N}$ Pesantunan 01. Hal ini bertujuan untuk menumbuhkan skap sadar lingkungan bagi anak usia sekolah dasar. Hal ini perlu adanya pelatihan dan penerapan anak usia sekolah dasar dalam membuang sampah secara tepat. Selanjutnya dilakukan evaluasi pada saat kegiatan sosialisasi. Kegiatan ini setidaknya dapat memberikan manfaat bagi sekolah yang mana dapat bermanfaat bagi kepala sekolah, guru, peserta didik dan warga sekitarnya dalam menerapkan lingkungan bersih.

Proses pengabdian kepada masyarakat ini dilakukan secara tertib dan aman. Dimana teknik analisis yang digunakan dengan menggunakan metode match a match. Metode ini merupakan model pembelajaran yang menyenangkan dan menjadi alternatif bagi anak dalam pemahaman dan pendalaman terkait dengan materi. Selain itu, anak menjadi semangat dan antusias dalam mengiktui pembelajaran. Langkah yang perlu dilakukan adalah membuat pertanyaan sesuai dengan materi, membuat kunci jawaban materi, membuat aturan pengharagaan untuk anak dan menyediakan lembaran untuk pasangan yang berhasil.

Metode ini diharapkan dapat membantu dalam kegiatan pengabdian. Huda menyatakan bahwa aspek kognitif dan psikomotorik pada pembelajaran match a match dapat melatih siswa agar lebih berani dalam berprestasi dan melatih kedisiplinan dalam menghargai waktu.

Media yang digunakan berupa gambar dan tanya jawab dalam memberikan sosialisasi. Gambar tersebut dimaksudkan agar anak dapat lebih mudah untuk memahami terkait dengan peduli lingkungan hidup. Gambar peduli lingkungan hidup tersebut diwujudkan dengan gambar jeni-jenis sampah yang sering dijumpai oleh anak dalam kehidupan sehari-hari.

Media gambar merupakan media pembelajaran yang paling sederhana dan umum dipakai dalam kegiatan pembelajaran. Media ini berkaitan dengan materi yang berfungsi untuk menyampaikan pesan kepada siswa. Materi dalam kegiatan pelatihan menumbuhkan sikap sadar lingkungan seperti, pengertian lingkungan, sikap sadar lingkungan dengan membuang sampah pada tempatnya, jenis-jenis tempat sampah dan bahaya membuang sampah tidak pada tempatnya. 
Media gambar dijadikan sebagai alat visual bagi anak agar lebih mendorong motivasi dalam belajar dan memudahkan dalam konsep yang abstrak menjadi sederhana. Selain itu, mengarahkan perhatian anak agar lebih berkonsentrasi terkait dengan materi pembelajaran. Dengan hal tersebut diharapkan dapat menjadi kelebihan dalam melaksanakan pengabdian. Media gambar yang digunakan dapat berupa fotografi. Media ini merupakan media gambar dari gambar aslinya dengan menggunakan sebuah alat digital yang berupa foto.

Menurut Widyaningrum (2019), sosialisasi program sekolah peduli dan berbudaya lingkungan dapat meningkatkan sikap peduli lingkungan dan ilmiah bagi siswa sekolah dasar. Program bersih sampah dapat dilakukan dengan pemilahan dan daur ulang sampah dapat dilakukan memalui media poster. Jadi, Media gambar ini dapat digunakan dalam melakukan sosialisasi terkait lingkungan hidup.

Selain media gambar, tanya jawab juga digunakan dalam pelatihan. Tanya jawab dilakukan untuk menambah pengetahuan dan wawasan bagi peserta didik tentang pentingnya lingkungan. Tanya jawab merupakan pembelajaran yang komunikatif, dimana sebelum mengawali pembelajaran peserta didik diberi stimulus terlebih dahulu. Selanjutnya mereka dilatih untuk menumbuhkan sikap akan sadar lingkungan sekitarnya.

\section{HASIL DAN PEMBAHASAN}

Lingkungan merupakan hal yang sangat penting bagi keberlangsungan hidup anak usia sekolah dasar. Oleh karena itu, dalam penerapnnya perlu adanya pemahaman terlebih dahulu terkait dengan materi peduli lingkungan. Anak terlebih dahulu diberi penjelasan terkait dengan lingkungan yang bersih dan bahayanya ketika tidak dapat menjaga dan melestarikan lingkungan. Pengertian akan lingkungan perlu dipahami agar anak dapat mengenal akan lingkungan dengan baik. Sehingga dalam penerapan sehari-hari dapat lebih mudah dan sesuai. Pemahaman anak usia sekolah dasar terkait dengan peduli lingkungan dapat ditunjukan pada Gambar 1.

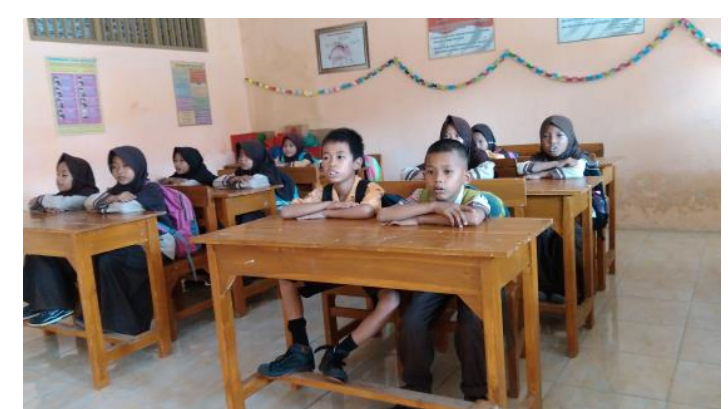

Gambar 1. Pemahaman tentang Lingkungan

Dari hasil observasi di SD Pesantunan, ditemukan sejumlah fakta bahwa peserta didi sekolah dasar sangat antusias dalam mengikuti kegiatan sosialis. Namun, anak membutuhkan sikap akan sadar lingkungan secara nyata. Selain itu, perlu adanya sarana dan prasarana yang menunjang dalam menumbuhkan dan mempraktekan akan sikap sadar lingkungan tersebut.

Sarana dan prasarana yang dibutuhkan dalam melaksanakan kegitan ini adalah tempat sampah yang memadai dalam mendukung kegiatan lingkungan. Dimana kebutuhan tempat sampah yang sesuai dengan lingkungan hidup. Yangmana tempat sampah yang tersedia harus dapat dibedakan antara lain sesuai dengan R3 (reduce, reuse dan recycle).

Kebutuhan akan sadar lingkungan sejalan dengan Narsi (2019) yang menyatakan bahwa ikap peduli lingkungan siswa kelas VI SD di Kota Ruteng dapat dikategorikan baik. Hal ini terlihat dari faktor kognisi dan afeksi. Faktor kognisi dapat ditunjukan dalam kesadaran dan faktor afeksi dapat ditunjukkan pada perasaan terkait dengan permasalahan lingkungan.

Sikap sadar lingkungan perlu ditanamkan oleh anak sejak dini. Dan sekolah perlu menfasilitasi akan adanya sarana dan prasarana terkait dengan kebersihan, ketertiban dan kelestarian lingkungan di sekolah. Sehingga terciptanya keberlangsungan hidup di sekolah.

Lingkungan sangat penting dalam keberlangsungan hidup anak usia sekolah dasar. Namun, hal tersebut perlu adanya kesadaran untuk menumbuhkan bagi anak. Kegiatan ini dapat dilakukan melalui penyuluhan, sosialisasi maupun pendampingan bagi anak. Tujuannya adalah 
agar tercapainya lingkungan hidup yang sehat dan bersih.

Menurut Apriani (2019), penyuluhan terkait dengan peduli lingkungan dapat dilakukan melalui poster dan gambar karakter dalam wadah sampah. Perancangan poster dan gambar karakter dapat digunakan sebagai media kampanye dalam pelaksanaan peduli lingkungan sekolah.

Kegiatan pengabdian yang dilakukan adalah dengan memberikan sosialisasi kepada anak usia sekolah dasar. Kegiatan tersebut dilakukan dengan menggunakan media gambar, agar mudah untuk dipahami oleh anak. Sehingga dalam penerapannya dapat terlaksana dengan baik.

Sikap sadar lingkungan dapat diasah melalui kegiatan sosialisasi dalam menambah pengetahuan dan wawasan terkait dengan lingkungan. Hal ini dimulai dari hal yang kecil yaitu memilah sampah organik dan organik. Setelah itu anak dapat membuang sampah pada tempatnya. Jadi, anak juga perlu pengetahuan terkait dengan jenis sampah yang tepat digunakan dalam membuang sampah.

Sikap sadar lingkungan merupakan kesadaran untuk mengarahkan sikap dan pengertian anak sekolah terhadap pentingnya lingkungan yang bersih dan sehat. Salah satu wujud sikap sadar lingkungan adalah membuang sampah pada tempatnya. Anak sekolah diwajibkan untuk membuang sampah pada tempat sampah yang telah disediakan.

Anak usia sekolah perlu mengetahui terkait dengan jenis-jenis sampah dan bagaimana cara membuang sampah yang benar. Pengenalan jenis-jenis sampah dan tempat sampah yang baik, dapat ditujukan pada Gambar 2.

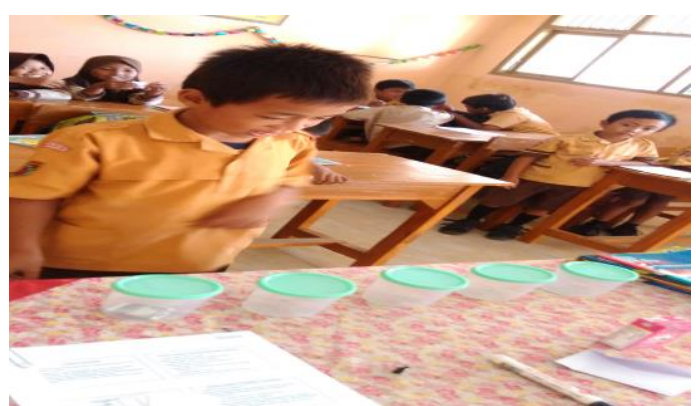

Gambar 2. Pengenalan Jenis-Jenis Sampah
Pengenalan jenis-jenis tempat sampah yang diberikan kepada anak yaitu jenis-jenis tempat sampah sesuai dengan undangundang, dapat dikelompokkan menjadi 5, yaitu tempat sampah organik, non-organik, bahan berbahaya dan beracun, daur ulang dan residu. Jenis pertama adalah tempat sampah organik yang berwarna hijau. Tempat sampah ini dapat mempercepat pembuatan kompos karena sudah dipisah dengan sampah anorganik maupun B3. Contoh: daun-daunan, bekas sayuran, dll.

Jenis kedua adalah Tempat sampah nonorganik yang berwarna kuning. Tempat sampah ini dapat mempermudah pemanfaatannya sebagai kerajinan daur ulang atau di daur ulang di pabrik. Contoh: Plastik bekas, gelas bekas air mineral, dll. Kemudian jenis ketiga adalah tempat sampah bahan berbahaya dan beracun yang berwarna merah. Tempat sampah ini digunakan dengan maksud agar tidak membahayakan orang lain. Contoh: sampah beling, kaca, gelas bening, bekas deterjen, obat nyamuk, dll.

Jenis keempat adalah tempat sampah daur ulang yang berwarna biru. Tempat sampah ini dimaksudkan untuk mempermudah proses daur ulang untuk kerajinan. Contoh: Kertas. Dan jenis kelima adalah tempat sampah residu yang berwarna abu-abu. Tempat sampah ini diisi selain 4 jenis tempat tersebut.

Jenis tempat sampah tersebut perlu diketahui oleh anak sekolah dasar. Agar dapat tertib dalam membuang sampah. Selain itu, tempat sampah juga perlu disediakan di sekolah. Hal ini bertujuan agar anak dapat mudah untuk memilah sampah yang akan dibuang.

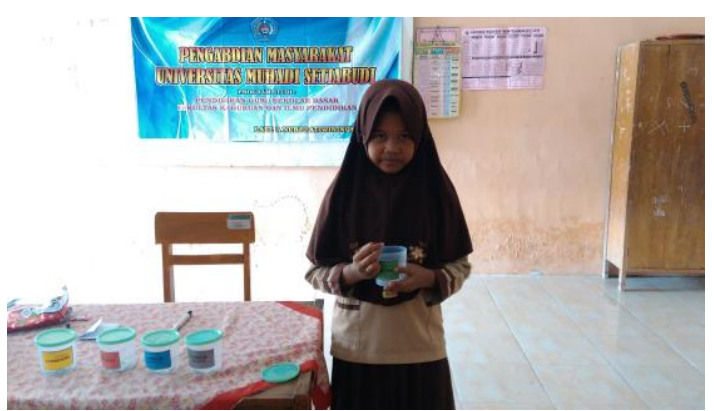

Gambar 3. Praktek Membuang Sampah pada Tempatnya 
Gambar 3 menunjukkan bahwa anak usia sekolah dasar dapat mempraktekkan bagaimana cara membuang sampah pada tempatnya. Dalam praktek telah disediakan 5 jenis-jenis tempat sampah yang dapat digunakan oleh anak untuk membuang sampah. Hal yang perlu diketahui oleh anak adalah jenis sampahnya terlebih dahulu yang perlu diketahui. Baru kemudian anak dapat membuang sampah sesuai dengan tempatnya. Warna dalam tempat sampah dapat mejadi ciri dan pengingat bagi anak dalam membuang sampah.

Pada proses pelatihan, anak-anak masih belum memahami mengenai jenis tempat sampah. Setelah diberi pemahaman, anak menjadi paham dan tahu terkait akan hal tersebut. Selain itu, peserta didik juga dapat membuang sampah sesuai dengan tempatnya. Sampah yang ada dapat dipilahpilih sesuai pada tempatnya. Hal yang perlu diingat bagi anak usia sekolah dasar adalah anak dapat mengerti akan jenis-jenis sampah dan tempatnya serta dapat menerapkan dalam kehidupan sehari-hari di lingkungan sekitar.

Pemilahan sampah ini perlu adanya sikap sadar dari anak. Yangmana sikap sadar lingkungan merupakan kesadaran untuk mengarahkan sikap dan pengertian anak sekolah terhadap pentingnya lingkungan yang bersih dan sehat. Salah satu wujud sikap sadar lingkungan adalah membuang sampah pada tempatnya. Anak usia sekolah dasar diwajibkan untuk membuang sampah pada tempat sampah yang telah disediakan.

Sikap sadar lingkungan ini juga didukung dari Ibu Kepala Sekolah, guru-guru dan penjaga sekolah. Hasil yang diharapkan dari kegiatan ini adalah adanya peningkatan kemampuan menumbuhkan sikap sadar lingkungan tersebut. Selain itu, dalam penerapannya hal ini tidak hanya dilakukan di sekolah tetapi dapat dilakukan di lingkungan keluarga maupun masyarakat. Maka dari itu perlu adanya dukungan dan partisipasi dari orang tua ketika akan menerapkannya di lingkungan keluarga.

Menurut Nuringsih (2018), partisipasi orang tua dalam menumbuhkan kesadaran lingkungan bagi siswa dapat dilakukan dengan dua kegiatan, yaitu mengingatkan kembali aktivitas ramah lingkungan dan pengenalan perilaku lingkungan. Kegiatan ini diharapkan mampu memotivasi anak agar sadar dalam berperilaku terhadap lingkungan.

Selain adanya partisipasi dari orang tua, dalam proses pelatihan anak-anak masih belum memahami mengenai jenis tempat sampah. Selain itu, anak usia sekolah dasar juga dapat membuang sampah sesuai dengan tempatnya. Sampah yang ada dapat dipilah-pilih.

Apabila anak sudah dapat memilah sampah dan membuang sampah pada tempatnya perlu adanya penanaman peduli lingkungan yang dapat diterapkan dalam sehari-hari. Menurut Lestari (2019), penanaman peduli lingkungan dapat dilakukan melalui pembiasaan, keteladanan, dan belajar menanamkan nilai peduli lingkungan. Lingkungan sebagai tempat pembelajaran dan media pembelajaran dapat menumbuhkan rasa ingin tahu dan peduli lingkungan. Budaya akan peduli lingkungan dapat memberikan dampak bagi makhluk hidup yang berada di sekitarnya.

Luaran yang dihasilkan dalam pengabdian adalah anak usia dasar memiliki pemahaman terkait pemilahan sampah yang benar dan tempat sampah yang sesuai dengan tempatnya sesuai dengan UndangUndang, serta dapat implementasi dari program dalam mewujudkan peduli lingkungan. Selain itu, adanya artikel ilmiah yang dapat diterbitkan dalam suatu jurnal pengabdian.

\section{KESIMPULAN}

Lingkungan merupakan hal yang penting bagi anak usia sekolah dasar. Anak perlu diberikan sosialisasi dan pendampingan terkait dengan peduli lingkungan. Pelaksanaan kegiatan sosialisasi dan pendampingan dalam menumbuhkan kesadaran lingkungan bagi anak usia sekolah dasar tersebut, dapat memberikan manfaat, antara lain: anak sangat antusias dalam mengikuti kegiatan menumbuhkan kesadaran lingkungan, anak memiliki pemahaman tentang sikap sadar lingkungan dan anak memiliki pemahaman tentang jenis-jenis sampah dan tempat sampah yang 
ada di lingkungan sekitar. Pendekatan kegiatan ini diberikan kepada anak usia sekolah dasar dalam menambahkan pengetahuan terkait dengan edukasi peduli akan lingkungan yang berada di sekitarnya. Serta dapat mengimplementasikannya dalam kehidupan sehari-hari. Sehingga kegiatan pengabdian ini dapat bermanfaat bagi anak usia sekolah dasar dan masyarakat sekitar.

\section{UCAPAN TERIMAKASIH}

Penulis mengucapkan terimakasih kepada beberapa pihak sebagai berikut.

1. Kepala Sekolah SDN Pesantunan 01 yang telah memberikan ijin untuk melaksanakan kegiatan pengabdian.

2. Para guru di SDN Pesantunan 01 yang telah berpartisipasi dalam kegiatan pengabdian.

3. Peserta didik di SDN Pesantunan 01 yang telah berpartisipasi dalam kegiatan pengabdian.

4. Lembaga Pembelajaran, Penelitian, dan Pengabdian kepada Masyarakat (LP3M) Universitas Muhadi Setiabudi yang telah mengijinkan kegiatan pengabdian.

\section{DAFTAR PUSTAKA}

Afriyeni, Yeni. (2018). Pembentukan Karakter Anak untuk Peduli Lingkungan yang ada di Sekolah Adiwiyata Mandiri SDN 6 Pekanbaru. Jurnal Pendidikan Anak Usia Dini, 1 (2). Diakses 15 juli 2020 dari

https://www.google.co.id/url?sa=t\&s ource=web\&rct=j\&url=https://journa l.unilak.ac.id/index.php/paudlectura/article/download/1171/835\&v ed=2ahUKEwjvtOfxr-

zqAhWHbSsKHWztAvwQFjADegQ ICRAB\&usg=AOvVaw20GpHTrihZ JFhrP8XaRJyH\&cshid=1595818164 $\underline{804}$.
Apriani, Hamidah. (2019). Perancangan Poster dan Wadah Sampah Karakter sebgai Media Kampanye Peduli Lingkungan SMP Islam Al Mustarih. Jurnal PKM: Pengabdian Kepada Masyarakat, 02 (02). Diakses 13 juli 2020 dari https://journal.lppmunindra.ac.id/ind ex.php/pkm/article/download/3073/2 $\underline{618 .}$

Huda, Miftahul. (2013). Model-Model Pengajaran dan Pembelajaran.Yogyakarta: Pustaka Pelajar.

Juariah, Siti, dkk. (2018). Jurnal Pengabdian Masyarakat. 2 (3). Diakses 13 juli 2020 dari https://www.google.co.id/url?sa=t\&sourc e=web\&rct=j\&url=https://core.ac.uk/do wnload/pdf/287316831.pdf\&ved=2ahUK EwjzofbK8t3qAhVXbn0KHSHCBdYQF jAAegQIARAB\&usg=AOvVaw3tE15hdN7CFFr8uuDDKiu.

Lestari, Yeni. (2018). Penanaman Nilai Peduli Lingkungan dalam Pembelajaran Ilmu Pengetahuan Alam. Jurnal Pendidikan Ke-SD-an, 4(2). Diakses 13 juli 2020 dari https://jurnal.untag-

sby.ac.id/index.php/semnasuntag/arti cle/view/1696/1441.

Narsi, Mikael, dkk. (2019). Analisis Sikap Peduli Lingkungan pada Siswa Kelas VI Sekolah Dasar di Kota Ruteng. Jurnal Pendidikan dan Kebudayaan. Diakses 13 juli 2020 dari https://ejournal.uksw.edu/scholaria/ar ticle/download/2594/1274.

Nuringsih, Kartika, dkk. (2019). Menumbuhkan Perilaku Peduli Lingkungan pada Siswa di Beji Timur, Depok. Jurnal Mitra, 3(1). Diakses 13 juli 2020 dari http://ejournal.atmajaya.ac.id/index.p hp/mitra/article/download/498/182.

Republik Indonesia. (2019). UndangUndang No. 32 Tahun 2009 tentang 
Perlindungan dan Pengelolaan Lingkungan Hidup.

Widyaningrum, Ratna, dkk. (2019). Penanaman Sikap Peduli Lingkungan dan Sikap Ilmiah Siswa Sekolah Dasar Melalui Sosialisasi Program Sekolah Peduli dan Berbudaya Lingkungan. Jurnal Adiwidya, II (1). Diakses 13 juli 2020 dari http://ejurnal.unisri.ac.id/index.php/a diwidya/article/download/2086/1856. 